\title{
The integrated approach to improve sustainable livelihood in Tello Island
}

\author{
Tunggul Sihombing \\ Department of Public Administration \\ USU \\ Medan, Indonesia \\ tunggul.toeng@gmail.com
}

\author{
Suparlan Lingga \\ Community Development Practitioner \\ Medan, Indonesia
}

\begin{abstract}
Almost half of the population of Indonesia live in rural areas and about $14.1 \%$ are living in below rural poverty line. Improving sustainable livelihood is an essential strategy to reduce the poverty in rural areas. Some Non-Governmental Organizations (NGOs) work with rural communities to improve sustainable livelihood through community based-development project. Working with poor communities in rural areas is challenging because each community has specific needs and characteristics. It also needs an integrated approach to ensure effectiveness, efficiency, and sustainability of the project. This paper provides acase study of community-based development project in a remote island (Tello Island) in South Nias, Indonesia. This island has rich natural resources but many people still live in poverty. MAP International, a NGO has worked in this island since 2011 to build the community's capacity to improve sustainable livelihood. The organization tried to support lowincome people through organic farming, fishing, livestock, and microloan program. The organization started the project with water filter distribution as 'an entry point' to gain community trust. The organization also established some learning groups among beneficiaries. After five years of project implementation, some significant outcomes have been achieved such as increased income, improved skills, and education. However, there are also some challenges particularly the project sustainability. In this paper, we evaluate the effectiveness, efficiency, and sustainability of the project. The paper also provides more details about project approach, special challenges (such as the new policy on transshipment ban that affects local fishing), and recommendation.
\end{abstract}

Keywords-sustainable livelihood, community-based development, integrated approach, poverty, increased income, improved skill

\section{INTRODUCTION}

Improving sustainable livelihood is an essential strategy to reduce the poverty in the developing world. The concept of sustainable livelihood does not only focus on certain aspects or manifestations of poverty such as low income, but also consider other vital aspects of poverty such as vulnerability and social exclusion. It offers a more coherent and integrated approach to poverty eradication. The 1992 United Nations Conference on Environment and Development declared that achievement of sustainable livelihoods is a broad goal for poverty eradication (Krantz, 2001). Following a big concern and strong advocacy for sustainable livelihoods approaches in community development, many development agenciesstarted to advocate livelihoods approaches as central to their programming and even organizational structure (Chambers and Conway, 1992; Ashley and Carney,1999).

Indonesia as one of the developing countries also struggle to eradicate the poverty particularly in rural areas. According to Central Bureau of Statistics or Badan Pusat Statistik (BPS) report, almost half of the population of Indonesia live in rural areas and about $14.1 \%$ are living in below rural poverty line (BPS report, 2016). It means that supporting poor people in rural areas will be very helpful to eradicate the poverty. Some Non-Governmental Organizations (NGOs) work with rural communities to improve sustainable livelihood through certain community based-development project. Many of them work with poor people living in marginalized areas such as remote island.

Tello Island is one of the remote-outer islands in the country, where community still lives in poverty and low health status. This island is administered under South Nias District, North Sumatera Province, Indonesia. It comprises of 17 villages spreading encircled the island with total population of 8,051 people $(1,877 \mathrm{HH})$. MAP International, a NGO has worked in this island since 2011 to build the community's capacity to improve sustainable livelihood. The organization develop a community-based development project called 'Total Health Village'. This project tried to support low-income people through organic farming, fishing, livestock, and microloan program. The overall objective of the project is to facilitate self-empower communities to be able to solve most of their own problems, and in such way people could increase their income and their life quality. The organization combines both livelihood and health aspects as a strategy to improve the quality of life of beneficiaries. The project started with water filter provision as 'an entry point' to gain community trust. Around 150 Sawyer Water Filters (SWFs) were distributed to the households who have problem with dirty domestic water.

After five years of project implementation, MAP wanted to evaluate the achievement and impact of the project. The objective of the evaluation is to identify project outcome,examine the effectiveness and efficiency of the intervention, and assess the relevance and sustainability of the project. This paper provides the main findings of the evaluation with more analysis on project approach and the real change in the communities. 


\section{METHODOLOGY}

\section{A. Household questionnaires}

Some enumerators gathered quantitative and qualitative data in the community through semi-structured questionnaires. There were 150 respondents of the survey (randomly selected) with proportional representative to cover all the components of intervention. These respondents are sufficient to represent the voice of the whole project beneficiaries ingeneral.

\section{B. Ten Seeds Technique(TST)}

This participatory tool directly gathers and ranks the information from the community. The evaluation team facilitated a special meeting of a group of community members (community's representative) and asked various questions regarding the project result. Using ten seeds to represent the community as a whole, the group was able to respond to specific question in terms of proportions and percentages. An evaluator acted as the facilitator to ask the question, and then a participant would move the seeds to indicate their opinion. The group was then asked if they agree or disagree and the seeds were adjusted until a consensus was reached (Jayakaran, 2002).

\section{Focus Group Discussion (FGD)}

The team continued to gather more rich information from various people through conducting several FGDs. FGD helped to fill out some missing information from the other method or to clarify particular issue, which was unclear before. There was a guideline prepared according to the inquiries set earlier and all answers received will weredirectlycross-checke during the sessions.The groups involved inFGD are farmers group, fishermen group, livestock breeder group, and small-business group.

\section{MAIN FINDING AND DISCUSSION}

\section{A. Project Approach}

MAP International used an interesting approach through initial intervention as an entry point to gain community trust in the beginning of project.The organization introduced and Sawyer Water Filter (SWF) as a way to produce clean and safe water at a household level. About 150 householdswho have problem with drinking water received the water filter. They paid this filter by contributing in community works such as cleaning public facilities (community center, church, mosque, etc) together.This approach was successful to gain community trust that boost community participation in the project stages.

The project also selected some key personsin the communities (chief of village, teacher, women group leader, youth group leader, etc) as the Community Own Resources Persons (CORPs) or "Soaneraigos" (local language). Those people would play a significant role to encourage and mobilize the community in the development process. The project also includes health education as integrated part of the project intervention. This is why the organization selected 34 Community Health Volunteers (CHVs) from 17 villages (2 per village).
The organization also established learning groups among beneficiaries (farmers, fishermen, livestock breeder, and businessman) that would also be functioned as selfempowerment groups. In these groups, beneficiaries could share and discuss their knowledge and experience in building skills (capacity) and solve the problems.

\section{B. Water Filter Provision}

This entry point is considered as one of the most relevant interventions for the beneficiaries. It is reasonable because $80 \%$ inhabitants depend on dug well to collect fresh water. Unfortunately, many of wells produce smelly and yellowish water, which is unhealthy to consume. In order to get clean water for drinking and cooking, people must use traditional filter (fabrics). The survey revealed that all filter recipients used to rely on dug well (private or public). The interviewees reported that water in well is blurred and smelly 89.2. The water filters were reported successful to clean the water (healthy) around $88 \%$ and $12 \%$ failed. techniques were reported successful $55.5 \%$, rarely $14.8 \%$ and failed 29.6 percent. In general, the use of water filter was efficient compared to traditional filter. In terms of whether their goal to get clean water achieved, it can be said that effectiveness around $89 \%$.

\section{Organic farming}

The organic farming intervention was facilitated to support the local farmers in producing more vegetables with organic method. Previously, the villagers depend mostly on cassava leaf and other wild vegetables harvested from other islands. Within organic farming, there were a series of activities, including knowledge and skill training on organic farming, gardening tools provision for the targeted beneficiaries and help the beneficiaries practiced the skill in their own locations. About 514 local farmers received farming tools (hoe, polybag, crowbar, etc), seeds, and training.Participants of the FGD acknowledged a fundamental change in plant cultivation by saying that they learnt new way of land preparation by using hoe.Majority farmers (interviewed) reported that currently their equipment (provided by project) is in good condition and seeds are finished. Only few farmers $(7.3 \%)$ have broken equipment (as can be seen in table 1).

Table 1. Current condition of the package

\begin{tabular}{|l|l|l|}
\hline Condition & Frequenc & $\%$ \\
\hline Equipment good & 10 & 24.4 \\
\hline Equipment good + seed empty & 13 & 31.7 \\
\hline Equipment broken & 3 & 7.3 \\
\hline Seed empty & 14 & 34.1 \\
\hline Seed available (not planted) & 1 & 2.4 \\
\hline Total & 41 & 100.0 \\
\hline
\end{tabular}

The evaluation results showed the project has been planting good seed in the mind of the 318 women $(71.8 \%)$ and increased their awareness, knowledge, and practice about the 
importance of developing organic vegetables. Most of them harvested good crops yield (mustard green, chili, string bean, tomato, and eggplant)and gained higher price at the local market.They could provide more nutritious food for their family and gained more income. This intervention is considered very effective and around $90 \%$ of respondents said that they were satisfied with the farming tools and training provided by the organization. Most of the training participants $(87 \%)$ have applied organic farming.

\section{Fishing}

This intervention helps and supports the local fishermen to increase their fishing production through providing needed tools and training. MAP distributed gill net to 130 fishermen and 25 ice boxes. Before receiving the gill net and ice boxes, the fishermen should be committed to transfer their knowledge and experience to other fishermen. The fishermen were also encouraged to educate other fishermen to stop fishing bomb. The distribution of gill nets and ice boxes has significantly helped the fishermen to increase fishing production so they could gain more income. Considering that some fishermen could not fish in bad weather (stormy season), the project also introduced fresh-water breeding (nile-tilapia, etc) as an alternative in bad weather.

The project team also tried to facilitate the local fish feed production through providing a simple engine of pellet production from local source (ingredients). The team encouraged the fishermen to identify (assess) some local source like cassava, coconut oil, corn, and some local fish (rucah). Then they were trained to make the local pellet (fish feed) by using all those ingredients. After several training and informal discussions, some fishermen could produce their own fish feed (pellet) from the local source in Tello island. Some women (fisherman's wife) were also trained to make alternative food production from fish such as fish ball, etc. In general, this intervention contributed significantly to increase family income.The fishermen group were also educated on healthy behavior such as stop smoking, drinking alcohol, etc.

The major challenge in this program is to find an addressable market for fish on Tello Island and (potentially) on the neighboring islands. Overall, the substantial increase in supply will lower the price of available fish - good for the consumer, but bad for the fisherman beneficiary. Because of an oversupply of fishes that are left unsold, the amount of fish that needs to be dried will increase, which is a problem because there is no working model to make money off of dried fish.

Unfortunately, the new policy on transshipment ban launched by Ministry of Fisher and it affected the selling of local fish. Many local fishermen could not sell their fish to outsider especially foreign buyers. This automatically decreased the price of fish (Jakarta Post, 2015). In this case, the government need to assess and consider many aspects before issuing the new public policy.

\section{E. Livestock}

The idea behind organic livestock production is creating a situation where the livestock contributes to the whole farm system and, at the same time, the system contributes to maintaining the animal's health and welfare and ultimate ability to exhibit its optimum physiological abilities and improve its immunity. The animal will in turn contribute to the recycling of nutrients, which will ensure proper resource utilization within the farm system and also improvement in the environment.Unlikeconventionalfarmingmethods, organiclivest ockfarmingrejectstheconcept of maximizing short-term performance and rather attempts to achieve an optimum life performance of the animal (Muwanga et al,2011).

The project team selected some local breeders to support pig and chicken breeding. There are 124 local people received piglets and chicken. They were also trained on organic pig pen (healthy animal cage). Some breeders have distributed their first piglets to their neighbor (as part of written agreement). Other breeders have also successfully created the new organic pig pen. However, there were some

pigs and chicken died due to certain diseases (as can be seen in table 2).

Table 2: livestock died or sold

\begin{tabular}{|l|c|c|}
\hline Selling & Frequency & $\%$ \\
\hline Not yet, pig death & 2 & 14,3 \\
\hline Not yet, chicken death & 3 & 21.4 \\
\hline $\begin{array}{l}\text { Not yet, pigs are still } \\
\text { vouno sold pigs } \\
\text { Ever sold }\end{array}$ & 3 & 21.4 \\
\hline Total & 14 & 42,9 \\
\hline
\end{tabular}

The result showed that five respondents had to bury their pigs or chicken (died) due to disease attack. This becomes a lesson learnt for future program, which means the project needs to anticipated disease threat for animal husbandry.

The results showed that 13 respondents out of 14 respondents $(92.9 \%)$ answered thatraising pigs and chicken are very important to meet their requirement of meat consumption; especially pig is valued for cultural ceremony (bride gift, funeral ceremony, etc). There were $42.9 \%$ respondents admitted that they used to purchase pig for cultural purpose; $36.7 \%$ received as relatives' gift, and $21.4 \%$ as revolving mechanism. Thus, by joined this project, they expected toprovidepigsbythemselvesforculturalceremonypurposes.

About $95 \%$ of training participants reported that training was highly relevant to increase their knowledge and skills in raising livestock.

\section{F. Microloan (Improving Business)}

The microloan program supported poor people to improve their life (business). The project team identified and selected local persons who are eligible for microloan (IDR 1 million to 5 million) to start their new business or expand their existing business. After 5 years, MAP has distributed IDR 105 million to 87 beneficiaries. Most of the beneficiaries used the loan to run their traditional shop (warung kelontong) that selling 
general household needs (like rice, salt, cooking oil, soap, etc) and the traditional cafe (warung kopi) which providing coffee, tea, and cookie. Some of them used the loan to run their small home industry (producing traditional soy, coconut oil). MAP supported those poor people through a holistic approach in which our team encouraged, assisted, and facilitated them to develop the appropriate business with good management and value. The team facilitated several informal discussions among beneficiaries, so they can share and learn together on how to develop the good business practice. They learned on how to serve the costumer, maintain good relationship, improve the product quality, and find out more market access. The team also encouraged them to be honest (keeping good integrity) in running the business.

The result showed that $50 \%$ of respondents were able to improve their microbusiness and were able to increase their profit by $33 \%$. This is also in line with their loan use, whichalmost all aiming for improving production and stock supplies. The evaluation noted that $50 \%$ of the respondents realized the need of saving as a solution for additional living costs, whilst half other felt the difficulties to balance saving with household expenses. In regards to efficiency, the survey found out that through a monthly installment, only $26,7 \%$ of the interviewee have secured funds more than IDR 500,000 whilst $45 \%$ reserved funds below IDR 200,000.

The major challenge in this program is how to link the microloan program with established microfinance (to ensure sustainability). In fact, there is no formal microfinance institution in the island except local Saving and Loan Groups (SLGs) that formed by MAP or local church. Most of the communities still not trust those Groups. It is very important to establish a good microfinance institution or support certain SLGs to be a modern Credit Union (CU).

\section{G. Summary of Capital Analysis}

It is also important to see the changes in livelihood capital assets including human, natural, physical, financial, and social capital when we evaluate the impact and sustainability of the project. Following the Chambers and Conway theory on sustainable rural livelihood, British Department For International Development (DFID) explain that "A livelihood comprises the capabilities, assets and activities required for a means of living. A livelihood is sustainable when it can cope with and recover from stresses and shocks and maintain or enhance its capabilities and assets both now and in the future, while not undermining the natural resource base" (DFID, 1999)".

In this evaluation, we also tried to assess the changes in capital as follows:

\section{1) Human Capital Asset}

The project brought changes to human capital development inmany ways, namely it increased knowledge and skills of the beneficiaries, opened opportunities for women to participate in productive division of works, reduced the burden of women in farming and filtering fresh water, and in crease health conditionof the beneficiaries. Many participants gained knowledge and skill on organic farming, fishing, livestock, small business, and even health.

\section{2) Natural Capital Asset}

In assessing changes in natural capital assets as results of program implementation, the emphasize is given to the effects of selected interventions on land quality and quantity, livestock production, access to fishing ground andwater source maintenance in relation to support food and livelihood security. Organic livestock has supported organic farming and fertile lands. The fishermen have opportunity to combine sea water fishing and fresh water cultivation fishing.

\section{3) Physical Capital Asset}

The physical/material assets of rural households refer to the tools and materials needed for production and livelihood, which mainly include: land and farm input, a safe residence, transportation means and equipment, household consumer goods, and sufficient clean drinking. Most of the beneficiaries have their own land for organic farming and they were also equipped with relevant tools to improve their livelihood.

\section{4) Financial Capital Asset}

A lot of beneficiaries gained more income through organic vegetable farming, livestock farming, fishing aid and in particular loan scheme for small business development. The strongest performance of the financial comes from microloan program which enable the beneficiaries to start new business or expand existing business for gaining more profit and ensuring sustainability.

\section{5) Social Capital Asset}

Established Community Own Resource Persons (CORPs) have brought leadership and inspiration to encourage collective action and participation in development process. It would reduce community dependency on project. Learning groups (beneficiary groups)are a social asset that can be functioned as vital forum to empower the community, sharing idea, and build good relationship. Those learning groups could produce trust among communities and they can be developed as CBOs in the future.

\section{CONCLUSION AND RECOMMENDATION}

The project has successfully achieved significant outcome and generated good impact to the quality life of the communities in Tello Island particularly for improving sustainable livelihood. The integrated approach that combines some interventions (plus health education) has encouraged more involvement (beneficiaries and other stakeholders) and maximized existing resource in the communities. The use of SWF provision as 'an entry point' was successful to gain community trust that boost community participation. Established learning groups also play an essential role in mobilizing communities and spreading knowledge and experience to other community members. After five years of project implementation, there are real changes in the communities covering livelihood capital asset (human capital, natural capital, physical capital, and social capital). Established 
In general, all main interventions (water filter provision, organic farming, livestock, fishing, and microloan) are efficient and effective. The result also shows that this project has a good prospective for sustainability.

Despite success story, the project also faced some challenges such as seeking potential market for oversupply of fish, linking beneficiary groups with microfinance institution, and maintain the learning groups. Considering that sustainability is very essential, the evaluation recommend the organization to link existing programs and beneficiaries with other related stakeholders (government institution, university, etc). The CORPs and learning groups can also be supported and facilitated to be the CBOs in the future.

\section{REFERENCES}

[1] Anonimous, "Evaluation Guidelines. Ministry of Foreign Affairs of Denmark. Evaluation Department, Ministry of Foreign Affairs of Denmark. 2006.

[2] Behailu, S, A. Kume and B. Desalegn, ,"Household's willingness to pay for] improved water service: a case study in Shebedino District, Southern Ethiopia. Water and Environment Journal 26 :429-434, 2012.

[3] BPS. Data dan Informasi Kemiskinan Kabupaten Kota tahun 2016.

[4] https://www.bps.go.id/website/pdf_publikasi/Data-dan-Informasi-

[5] Kemiskinan-Kabupaten-Kota-2016--.pdf (accessed September 1, 2017)

[6] Burlew, R., A. Puckett, R. Bailey, M. Caffrey, and S. Brantley," Assessing the relevance, efficiency, and sustainability of HIV/AIDS inservice training in Nigeria. Human Resources for Health 12:20, 2014.

[7] Carney, D. (ed.) Sustainable Rural Livelihoods: What contribution can we make?. London: DFID, 1998.

[8] Chambers, R. and G. Conway. 'Sustainable rural livelihoods: practical concepts for the21st century. IDS discussion paper, 296. Brighton: IDS. 1992.

[9] Cramm, J.M., S. Phaff and A. P. Nieboer, 2013. The role of partnership[22] functioning and synergy in achieving sustainability of innovative programmes in community care. Health and Social Care in the Community 21(2), 209-215.

[10] DFID Sustainable Livelihoods Guidance Sheets. London: DFID, 1999.

[11] Dilley, M, T. E. Boudreau,"Coming to terms with vulnerability: a critique of the food security definition. Food Policy $26: 229-247,2001$.

[12] Doss, Ch., M. Truong, G. Nabanoga and J.Namaalwa. Women, Marriage

[13] and Asset Inheritance in Uganda. Development Policy Review 30(5): 597-616, 2012.

[14] Jakarta Post. Susi defends transshipment ban.

[15] http://www.thejakartapost.com/news/2015/01/27/susi-defends-

[16] transshipment-ban-set-issue-guidelines.html (accessed September 2, 2017)

[17] Knutsson P. "The Sustainable Livelihoods Approach: A Framework for Knowledge Integration Assessment. Human Ecology Section. ttp://www.humanecologyreview.org/pastissues/her131/knutsson.pdf(acc essed August 13, 2017).

[18] Mahdi, Ganesh P, Shivakoti, and Dietrich Schmidt-Vogt, Livelihood Change and Livelihood Sustainability in the Uplands of Lembang Subwatershed, West Sumatra, Indonesia, in a Changing Natural Resource Management Context. Environmental Management43:84-99.

[19] Mazur, E.R., and Butler, M.M., Principles and processes for enhancing Sustainable rural livelihood: Collaborative learning in Uganda. International Journal of Sustainable Development \& World Ecology Vol 14 (2007): 604-617.

[20] Nalubwama, S.M. , A. Mugisha and M. Vaarst. Organic livestock production in Uganda: potentials, challenges and prospects. Trop Anim Health Prod 43:749-757, 2011.

[21] Sebotsa, M. L. D, A. Dannhauser, P. L. Jooste and G. Joubert Assessment of the sustainability of the iodine deficiency disorders control program in Lesotho. Food and Nutrition Bulletin, 2007 vol. 28, no. 3. The UnitedNations University.

[22] Scoones, I. 'Sustainable Rural Livelihoods: A Framework for Analysis'. Working Paper72. Brighton: IDS, 1998.

[23] Speranza, Ch. I," Buffer capacity: capturing a dimension of resilience to climate change in African smallholder agriculture. Reg Environ Change 13:521-535,2013. 